\title{
EFFECT OF SCORPION TOXIN ON THE ENTEROCHROMAFFIN-LIKE CELLS IN NORMAL AND Trypanosoma cruzi-INFECTED RATS: A MORPHOLOGICAL STUDY ${ }^{(1)}$.
}

\author{
N. H. TOPPA (2), V. H. R. LEITE (2), A. J. A. BARBOSA (2), E. CHIARI (3), II. M. S. GONZAGA (3),
} L. FREIRE-MAIA (3) \& J. R. CUNIIA-MELO (4)

\begin{abstract}
SUMMARY
Intravenous injection of scorpion toxin (Tityus serrulatus) in normal and Trypanosoma cruzi infected rats did not cause ultrastructural morphologic changes on enterochromaffin-like (ECL) cells of the stomach, although it induced a significant increase of the gastric secretion.

Our data seem to indicate that gastric ECL cells structure is not affected by stimulation with scorpion toxin or by acute infection with $\mathbf{T}$. cruzi in the rat
\end{abstract}

KEY WORDS: Enterochromaffin like cells; scorpion toxin: Trypanosoma cruzi; rat: gastric secretion.

\section{INTRODUCTION}

The ECL cells of the stomach present the basic morphological characteristics of the APUD cells ${ }^{29}$. ${ }^{0}$. They are relatively numerous in oxyntic mucosa of rodents and could synthesize, store and secrete histamine, 5-hydroxytryptamine and peptides ${ }^{3.4}$. 17. 18. 19. 32. 39. 40 . The secretory activity of these cells seems to be regulated by the vagi nerves and by the hormone gastrin ${ }^{20}$. 22, 23, 25. Incubation of ECL cells in a medium containing catecholamines and acetylcholine has shown that epinephrine increases the volume of the secretory vesicles and decreases the density of its osmiophilic core ${ }^{33}$.

The toxin from the Brazilian scorpion Tityus serrulatus induces gastric acid and pepsin secre- tion either "in vivo" and "in vitro" "9. 10. 16. 17. This effect seems to be secondary to depolarization of autonomic post-ganglionic nerve endings in duced by the toxin with consequent release of chemical mediators such as acetylcholine, cate cholamines and histamine ${ }^{13.14}$. On the other hand, the scorpion toxin enhances the gastric wall contents of histamine in normal ${ }^{11}$ and $\mathbf{T}$. cruzi-infected rats ${ }^{1}{ }^{10}$. Furthermore, the main source of histamine in the rat stomach is supposed to be the ECL cell ${ }^{18 .}{ }^{19.24}$.

Acute infection by $\mathbf{T}$. cruzi leads to a decrease in the number of neurons and ganglia of the intramural plexuses of the digestive tract ${ }^{36 .}{ }^{37}$. ${ }^{38}$ and depletion of chemical mediators in rat

(1) Trabalho realizado com auxilio financeiro da FINEP e CNPq

(2) Departamento de Anatomia Patológica e Medicina Legal da Faculdade de Medicina da UFMG. Belo Horizonte. MG, Brasil.

(3) Instituto de Ciéncias Biológicas da UFMG. Belo Horizonte. MG, Brasil.

(4) Departamento de Cirurgia da Faculdade de Medicina da UFMG. Belo Horizonte, MG. Brasil.

Address for correspondence: Dr. Nivaldo H. Toppa. Faculdade de Medicina da UFMG, Departamento de Anatomia Patológica e Medicina Legal. Av. Alfredo Balena, 190. CEP 30130 Belo Horizonte, MG, Brasil. 
TOPPA, N. H.; LEITE, V. H. R.; BARBOSA. A. J. A.; CHIARI. E.; GONZAGA, H. M. S.; FREIRE MAIA, L. \& CUNHA. MELO, J.R. - Effect of scorpion toxin on the enterochromaffin-like cells in normal and Trypanosoma cruzi-infected rats: a morphological study. Rev. Inst. Med. trop. Säo Paulo, 31 (1): 7.13, 1989

heart and mouse colon ${ }^{26,27,28}$. These effects on rats were only observed when the experiments were performed around the 20th day of infec tion $^{26.27}$. A similar model has been used to study the effects of T. cruzi infection upon the morpho logical characteristics of ECL cells present in the rat stomach. In the present work we proposed to study the ultrastructure of ECL cells of the stomach of both normal and of $\mathbf{T}$. cruzi-infected rats under the effect of scorpion toxin.

\section{MATERIAL AND METHODS}

Thirty-five to 45 days old, male albino rats ( $n=42$ ), with an average weight of $180 \mathrm{~g}$ were divided in 4 groups in the present study: I rats injected with saline $(\mathrm{n}=14)$; II - rats inoculated with $\mathbf{T}$. cruzi and injected with saline (n = 14); III - rats injected with scorpion toxin $(n=9)$; IV - rats inoculated with $\mathbf{T}$. cruzi and injected with scorpion toxin $(n=5)$. Nineteen days old rats of groups II and IV were inoculated with the $\mathbf{Y}$ strain of $\mathbf{T}$. cruzi by intraperitoneal route (4000 trypomastigotes/g). The parasitism was confirmed two weeks later and the experiments conducted when the rats were 40 days old. Food, but not water, was withdraw 18-24 hours before the experiments. The animals were then anesthetized with an intraperitoneal injection of urethane $(140 \mathrm{mg} / 100 \mathrm{~g})$ and the trachea and right jugular vein were cannulated. A bolus injection of saline or scorpion toxin $(25 \mu \mathrm{g} / 100$ g) were injected through the jugular catheter. The animals were then killed 60 minutes later by section of abdominal segment of aorta and caval vein. The esophagus and pylorus were ligated and the whole stomach excised. The gastric juice was collected for the assessment of volume, acidity and peptic activity. To determine the sample acidity the gastric juice was transferred to a $10 \mathrm{ml}$ beaker and titrated with $0.01 \mathrm{~N} \mathrm{NaOH}$ to $\mathrm{pH} 7.4$ using a tiny burette. The pepsin output was measured according to the modified method of ANSON ${ }^{2,6}$. Fragments of oxyntic mucosa were fixed in $10 \%$ formol solution for 18 hours and were processed according to conventional histological techniques for optical microscopy stu dies. Sections of $5,0 \mu \mathrm{m}$ were stained by hemato $x y l i n$ and eosin and by silver impregnation. The ECL cells were counted in all sections. The area of each section was measured by a planimeter and the results were expressed as number of cells per $\mathrm{mm}^{2}$. In the groups II and IV only the animals with lesions of the intramural plexuses were processed for ultrastructural studies of the ECL cells. To perform these studies slices of oxyntic mucosa from animals shown to have nerve da mage were collected and fixed for 3 hours in 0,2 $\mathrm{M}$ phosphate buffered $3 \%$ glutaraldehyde, $\mathrm{pH}$ 7.2 , followed by two hours fixation in $0,1 \mathrm{M}$ phos phate buffered $1 \%$ osmium at $4 \mathrm{C}$. Semi-thin sec tions were obtained and stained for analysis of the tissue morphology. The ultra-thin sections were obtained at the level of one third of the basal portion of the mucosa in an ultra microtome Porter-Bloom MT1. Sections were stained with uranile acetate and lead citrate and examined in Zeiss EM-9 S2 electronic microscope.

A total of $253 \mathrm{ECL}$ cells were analysed: 70 from group I; 91 from group II; 51 from group III and 41 from group IV. The photographs were taken and amplified, giving a final magnification of 20480 folds. The perimeter of all ECL cells, plasmatic and nuclear membranes as well as the granular and clear vesicles and dense core granules were reproduced on a transparent sheet. The areas of these structures were measured by a planimeter and expressed in $\mu \mathrm{m}^{2}$. All granular and clear vesicles contained in the ECL cells we re counted. Data were compared by the analysis of variance and differences were taken as significant when $\mathbf{P}<0,05$. Results were expressed as mean \pm SEM.

\section{RESULTS}

The distribution and morphological aspects of the ECL cells in the oxyntic mucosa of rat stomach as demonstrated by optical microscopy were the same as described elsewhere ${ }^{7.26 .40}$. The Auerbach's plexus of the stomach of acutely $\mathbf{T}$. cruzi-infected rats showed the characteristic lesions: ganglionitis, periganglionitis and neuronal degeneration. On the other hand several other organs such as heart, liver, spleen and cecum also showed signs of severe parasitism. In spite of these alterations no morphological or numerical changes of the ECL cells were detec ted under these light microscopy studies (Figure 1 and Table 1).

In all groups, at the electron microscopic examination, the ECL cells were pyramidal or 
TOPPA, N. H.; LEITE, V. H. R.; BARBOSA, A. J. A.; CHIARI, E.; GONZAGA, H. M. S.; FREIRE-MAIA, L. \& CUNHAMELO. J. R. - Effect of scorpion toxin on the enterochromaffin-like cells in normal and Trypanosoma cruzi.infected rats: a morphological study. Rev. Inst. Med. trop. Sảo Paulo, 31 (1): 7-13, 1989
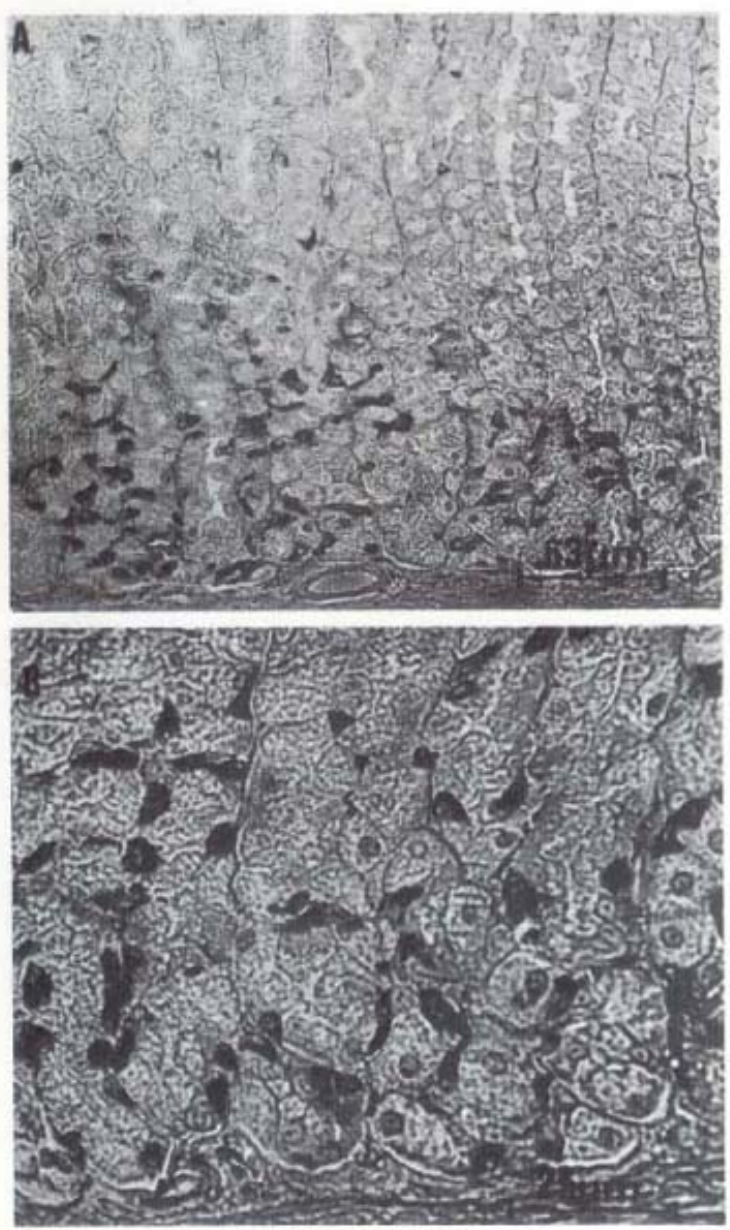

Fig. 1 - A and B. ECL cells distribution in oxyntic mucosa of rat stomach. The dark color is due to silver impregnation of ECL cells (Grimelius stain).
TABLE 1

ECL cells inumber per $\mathrm{mm}^{2}$ in oxyntic mucosa of rat stomach in control, $\mathbf{T}$. cruzi-infected, scorpion toxin and $\mathbf{T}$. cruzi-infec ted + scorpion toxin groups

\begin{tabular}{lc}
\hline Groups (n) & Number of ECL cells $/ \mathrm{mm}^{2}$ \\
\hline I - Control (14) & $103 \pm 26$ \\
II - T. cruzi-infected (14) & $126 \pm 36$ \\
III - Scorpion toxin (9) & $107 \pm 19$ \\
IV - T. cruzi-infected + & $119 \pm 32$ \\
Scorpion toxin (5) & \\
\hline
\end{tabular}

Values represent the mean $\pm S E M$

T. cruzi-infected rats ( $Y$ strain): 4000 trypomastigotes/g, i. p., 20 days before the experiments.

Animals from group I and II were injected with saline and from groups III and IV with scorpion toxin $(25 \mu \mathrm{g} / 100 \mathrm{~g})$.

Statiscally significant differences between groups were not observed

irregular in shape and frequently presenting a thin cytoplasmic process which could be seen between parietal and zimogenic cells (Figure 2). Most of the ECL cells were adjacent to the basal membrane without communication with the glandular lumen (Figure 2). The granular vesicles presented an electron-dense, excentric core separated from the membrane by a wide clear halo (Figures 3 and 4). The agranular vesicles did not present any electron dense content. Among the vesicles, the endoplasmic reticulum, mitochondria, Golgi apparatus and free ribosomes were sparse. The nucleus of ECL cells was ovoid or irregular in shape. The chromatin sho wed a tendency to form clumps close to the nuclear membrane which presented a number of

TABLE 2

Average number of enterochromaffin -like cell secretory vesicles per $\mu \mathrm{m}^{2}$ of cytoplasm in rat $\mathrm{stomach}$.

\begin{tabular}{|c|c|c|c|}
\hline \multirow{2}{*}{ Groups $(n)$} & \multirow{2}{*}{ Number of ECI cells } & \multicolumn{2}{|c|}{ Number of vesicles $/ \mu \mathrm{m}^{2}$} \\
\hline & & Granular & Clear \\
\hline I - Control (14) & 70 & $0,79 \pm 0,06$ & $0,61 \pm 0,07$ \\
\hline II - T. cruzi-infected (14) & 91 & $0,93 \pm 0,06$ & $0,49 \pm 0,05$ \\
\hline III - Scorpion toxin (9) & 51 & $0,74 \pm 0,09$ & $0,43 \pm 0,07$ \\
\hline IV $-\mathbf{T}$. cruzi-infected + Scorpion toxin (5) & 41 & $0,55 \pm 0,04$ & $0,42 \pm 0,08$ \\
\hline
\end{tabular}

Values represent the mean $\pm \mathrm{SEM}$

T. cruzi-infected rats ( $Y$ strain): 4000 trypomastigotes/g, i. p., 20 days before the experiments

Animals from group I and II were injected with saline and from groups III and IV with scorpion toxin $(25 \mu \mathrm{g} / 100 \mathrm{~g})$.

Statiscally significant differences between groups were not observed. 
TOPPA, N. H.; LEITE, V. H. R.; BARBOSA, A. J. A.; CHIARI, E.; GONZAGA, H. M. S.; FREIRE-MAIA, L. \& CUNHA. MELO, J.R. - Effect of scorpion toxin on the enterochromaffin -like cells in normal and Trypanosoma cruzi-infected rats: a morphological study. Rev. Inst. Med. trop. São Paulo, 31 (1): 7-13, 1989.

TABLE 3

Area $\left(\mu \mathrm{m}^{2}\right)$ of the enterochromaffin-like cell secretory vesicles (granular vesicles, clear vesicles and core)

\begin{tabular}{lccc}
\hline Groups (n) & Granular vesicles & Clear vesicles & Core \\
\hline I - Control (14) & $0.15 \pm 0,011$ & $0,18 \pm 0,011$ & $0,02 \pm 0,012$ \\
II - T. cruzi-infected (14) & $0,17 \pm 0,009$ & $0,18 \pm 0,013$ & $0,03 \pm 0,009$ \\
III - Scorpion toxin (9) & $0,15 \pm 0,009$ & $0,17 \pm 0,013$ & $0,03 \pm 0,019$ \\
IV - T. cruzi-infected + Scorpion toxin (5) & $0,15 \pm 0,01$ & $0,18 \pm 0,010$ & $0,03 \pm 0,012$ \\
\hline
\end{tabular}

Values represent the mean $\pm \mathrm{SEM}$ for 5 to 14 experiments.

T. cruzi-infected rats (Y strain): 4000 trypomastigotes/g, i. p., 20 days before the experiments. Animals from group I and II were injected with saline and from groups III and IV with scorpion toxin $(25 \mu \mathrm{g} / 100 \mathrm{~g})$.

Statiscally significant differences between groups were not observed.

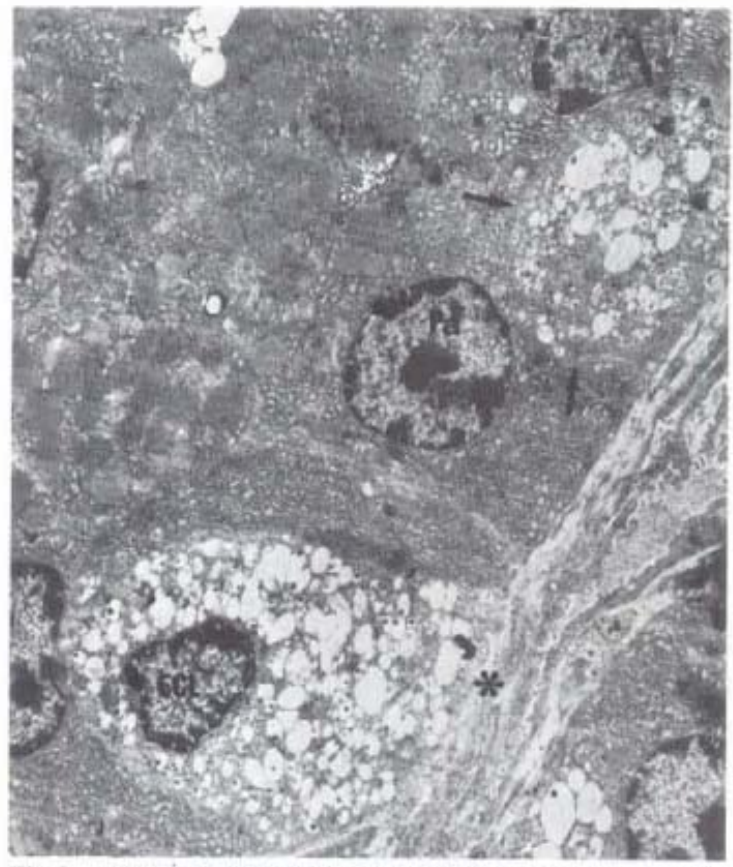

Fig. 2 - An enterochromaffin-like cell (ECL) and a cytoplasmic process (arrows) are lying on the basement membrane $(\mathcal{*}$ ) and adjacent to a parietal cell (PA) (X 7.780).

pores. Data showing the measurements of ECL cells vesicles and cores are presented in Tables 2 and 3 , and no significant differences between the groups were detected. The dose of scorpion toxin used induced a great increase in volume, acidity and peptic activity of gastric juice when compared to controls (Table 4).

\section{DISCUSSION}

The intravenous injection of purified scorpion toxin from the Brazilian scorpion Tityus serrulatus in rats induces an increase on gastric secretion of acid and pepsin ${ }^{9,}{ }^{10}$. This effect de pends on the action of acetylcholine and hista mine as it is blocked either by atropine or cimeti dine $e^{9}$. On the other hand, the toxin induces a significant increase in the gastric content of histamine in the rat. It has been reported that the main source of histamine in the oxyntic mucosa

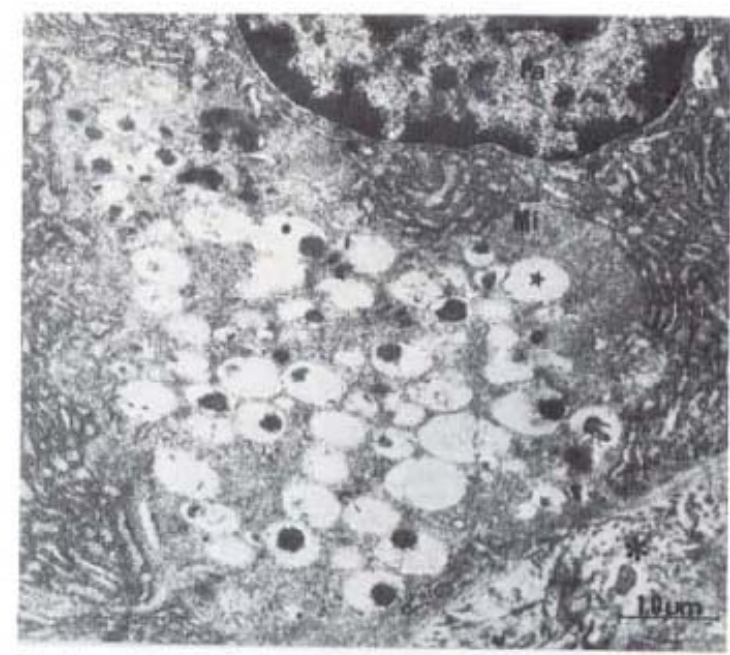

Fig. 3 - Detail of eytoplasmic process of an enterochromaf fin-like cell presenting granular (") and clear ( $\downarrow$ ) vesicles PA = nucleus of an adjacent parietal cell: $\mathrm{Mi}=$ mitochondria (*) basement membrane (X 20.480). 
TOPPA, N. H.; LEITE. V. H. R.: BARBOSA, A. J. A.; CHIARI, E.: GONZAGA, H. M. S.; FREIRE-MAIA, L. \& CUNHAMELO, J. R. - Effect of scorpion toxin on the enterochromaffin like celis in normal and Trypanosoma cruzi-infected rats: a morphological study. Rev. Inst. Med. trop. São Paulo, 31 (1): 7-13, 1989.

TABLE 4

Effect of scorpion toxin on gastric secretion of acid and pepsin in the rat

\begin{tabular}{lccc}
\hline Groups (n) & Volume (ml) & $\begin{array}{c}\text { Acid output } \\
\boldsymbol{\mu E q} / \mathrm{h}\end{array}$ & $\begin{array}{c}\text { Pepsin output } \\
\boldsymbol{\mu} \mathrm{mol} / \mathrm{h}\end{array}$ \\
\hline I - Control (6) & $0,4 \pm 0,05$ & $11,5 \pm 1,9$ & $0,6 \pm 0,1$ \\
II - T. cruzi-infected (6) & $0,5 \pm 0,1$ & $23,0 \pm 4,0$ & $3,7 \pm 0,6$ \\
III - Scorpion toxin (6) & $2,1 \pm 0,3^{*}$ & $128,0 \pm 8,4^{*}$ & $16,6 \pm 0,9^{*}$ \\
IV - T. cruzi-infected + Scorpion toxin (6) & $1,9 \pm 0,2$ & $139,6 \pm 26^{*}$ & $18,5 \pm 3,0^{*}$ \\
\hline
\end{tabular}

Values represent the mean $\pm \mathrm{SEM}$ for 8 experiments

T. cruzi-infected rats ( $Y$ strain): 4000 trypomastigotes/g, i. p., 20 days before the experiments. Animals from group I and II were injected with saline and from groups III and IV with scorpion toxin $(25 \mu \mathrm{g} / 100 \mathrm{~g})$.

* Statistically different from control group injected with saline and from chagasic rats injected with saline $\mathrm{P}<0,05$.

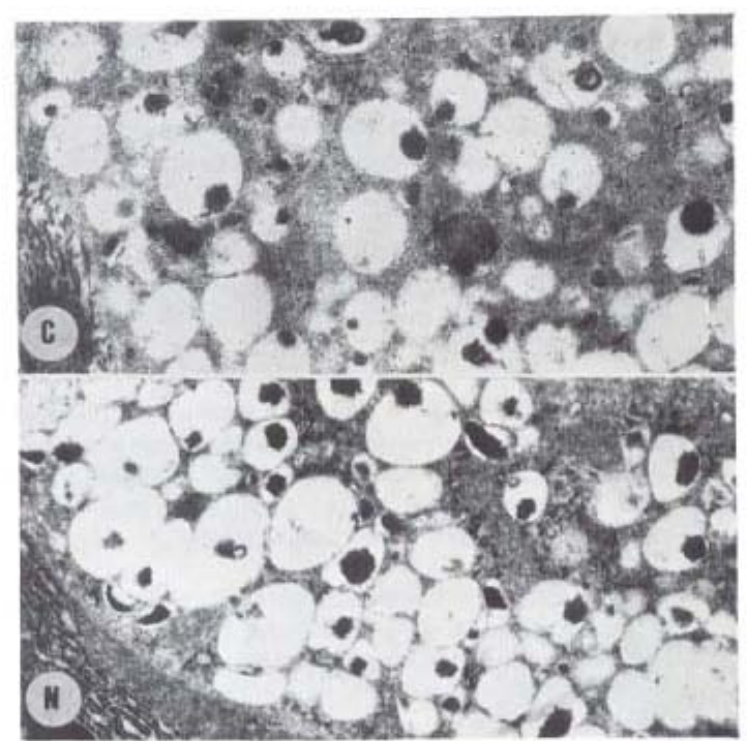

Fig. 4-Granular and clear vesicles of T. cruzi-infected (C) and normal (N) rats after scorpion toxin $(25 \mu \mathrm{g} / 100 \mathrm{~g})$. There are no morphologic differences. (X 20480 ).

of the rat are the ECL cells ${ }^{18}, 19,35$. The morphologic characteristics of those cells make them easily recognized at electron microscope due to their typical secretory granules. In the present work the ultrastructural analysis of ECL cells has shown the same morphological pattern described elsewhere ${ }^{7}, 12,21.24,30,31.34 .40$. Although the scorpion toxin has induced an increase in gastric secretion and in the histamine content of the rat stomach ${ }^{11}$, our data has not shown ultrastructural changes in the ECL cells in both normal and $\mathbf{T}$. cruzi-infected rats under its effect. If the scorpion toxin induces an increase of histamine content in the rat stomach, one should expect for modifications in the ultrastructure of the ECL cells in the animals inoculated with toxin once these cells are said to be the main source of gastric histamine in rats. However, this was not found. Some hypothesis can be raised to explain the results: a - it might well be that the secretory granules of ECL cells in the stomach contain other chemical mediators, for example peptides. In that way, only the release of histamine would not be enough to induce changes in the morphological characteristics of the cells; $\mathrm{b}$ - the histamine present in ECL cells would not participate in the process of gastric secretion. In this case the main source of histamine could be the mast cells. This possibility is reinforced by the fact that either normal and T. cruzi-infected rats, when inoculated with scorpion toxin, showed an increase in the number of mast cells present in the gastric wall of the rat in both, glandular and membranous regions ${ }^{1 .}{ }^{10} ; \mathrm{c}$ - the scorpion toxin would not have acted on the ECL cells in the condition of the present experiment, although it had induced a substancial increase of volume, acidity and peptic activity of gastric juice; $d$ - the 60 minutes, time elapsed between the injection of the toxin and the collection of the gastric juice, would have been sufficient for restoration of the original components of the ECL cells. For example, in spite of the release 
TOPPA. N. H. LEITE, V. H. R.; BARBOSA, A. J. A.: CHIARI, E.; GONZAGA, H. M. S.; FREIRE-MAIA, L \& CUNHA MELO, J.R. - Effect of scorpion toxin on the enterochromaffin-like cells in normal and Trypanosoma cruzi-infected rats: a morphological study. Rev. Inst. Med. trop. Sãe Paulo, 31 (1): $7.13,1989$.

of histamine the intracellular stores might have been replaced by means of a rapid turnover".

The acute infertion with $\mathbf{T}$. cruzi was em. ployed in order to obtain an intrinsic denervation. This in fact has occurred as morphological studies of the Auerbach plexus of the stomach under ordinary light microscopy was done and all the animals studied have shown a ganglionitis and a partial destruction of neurones and nerve endings

The ECL cells have shown similar ultras. tructural characteristics either in normal rats or in $\mathbf{T}$. cruzi-infected animals inoculated with saline or with scorpion toxin. In the present model we do not know if the denervation has been sufficient to impair the functional integrity of ECL cells as described by other authors ${ }^{20.25}$ On the other hand, the gastroenteric neurons consti. tute an heterogenous population ${ }^{8.15}$ and if the ECL cells are influenced by a definite type of neuron an experimental model with selective de nervation would be useful to clarify the present question.

\section{RESUMO}

Efeito da toxina escorpiônica sobre as células enterocromafins-like de ratos normais $e$ infectados pelo Trypanosoma cruzi

A injeção intravenosa de toxina escorpioni. ca (Tityus serrulatus) em ratos normais e infec. tados pelo Trypanosoma cruzi nāo causou alte raçōes morfológicas ultra-estruturais das células enterocromafins like (ECL) do estômago, embora tenha induzido a aumento significativo da se creçāo do suco gástrico.

Nossos resultados parecem indicar que a es trutura das células ECL do estômago de ratos não é afetada pela estimulação com a toxina escorpiônica ou pela infecção aguda pelo T. cruzi.

\section{REFFRENCES}

1. ALMEIDA. A. P: GOBBI. H.: TOPPA. N. H: CHIARI E. GONZAGA, H M S : GOMEZ, M V.: FREIRE MATA L. \& CUNHA MELO, J. R. - Gastric Acetylcholine and histamine content in normal and Trypanosoma cruri-in. fected rats Braz J. med biol. Res., (submitted)
2. ANSON. M. L. - The stimulation of pepsin. trypsin. papain and cathepsin with hemoglobin I gen Physiol.s 22 : 79-89. 1938

3 AURES. D. W \& HAKANSON, R. - Histidine decarbo xylase and DOFA decarboxylase in the stomach of develo ping rat Fxperientia, 24: 666-667, 1968

4 AURES, D. W. HAKANSON, R \& SCHAUER, A. - Histi dine decarboxylase and DOPA decarboxylase in the rat stomach. Properties and cellular localization Europ. J Pharmacal., 3. 217234,1968

5. BEAVEN, M A. - F actors regulating availability of hista mine at tissue receptors In: GANELLIN, G. R. \& PAR SONS, M. E. ed. - Pharmacology of histamine receptors. Bristol Wright PSG. 1982. cap. 3. p. 103.145

6 BERSTAD, A -- A modified hemoglobin substrate me thod for the stimulation of pepsin on gastric juice. Srand J. Gastroent, 5: 343-348, 1970

7 CAPELLA, C.: VASSALLO. G \& SOLCIA, E. - Ligh and electron microscopic identification of the histamine storing argyrophil (ECL) cell in murine stomach and of its equivalent in others mammals. Z. Zellforsch., 118 68-84, 1971

8 COOK, R. \& BURNSTOCK, G. - The ultrastructure of Auerhach's plexus in the guinea pig I. Neuronal elements J. Neuroeytol, 5: $171-194.1976$

7. CUNHA-MELO, J.R.: GONZAGA, H. M. S ; ALZAMORA F \& FREIRE MAIA, L - Effects of purified scorpion to xin itityustoxin: on gastric secretion in the rat. Toxicon. 21: $843-848.1983$

10 CUNHA-MELO. J. R. - Efeito da toxina purificada do escorpiāo Tityus serrulatus (tityustoxina) sobre a secreçáo gástrica de ratos normais e chagásicos. Belo Horizonte. 1985. Tese de doutoramento - Faculdade de Medicina da Vniversidade Federal de Minas Gerais:

11. CINHA MELO, J R : ALMEIDA, A P ; GONZAGA, H M. S : GOMEZ, M. V. \& FREIRE-MAIA, L. - Effect of scorpion toxin on gastric histamine and acetylcholine content in the rat, Braz. J. med. biol. Res, 20: 393-401. 1987

12. FORSMANN, W. G,: ORCI. L.; PICTET, R.: RENOLD A. E. \& ROVIL.LER, C. - The endocrine cells in the epithe. lium of the gastrintestinal mucosa of the rat J. Cell. Biol. 40: $692,715,1969$

13. FREIRE-MAIA, L ; CUNHA MELO, J, R : FUTIRONE TO, H. A.; AZEVEDO, A. D. \& WEINBERG. J. - Choli nergic and adrenergic effects of tityustoxin. Gen. Pharmacol. 7: 15.121, 1976

14. FREIRE-MAIA, L ; ALMEIDA, H O : CUNHA-MELO, J R: AZEVEDO. A. D. \& BARROSO, J. - Mechanism of the pulmonary edema induced by intravenous injection of the scorpion toxin in the rat. Agents and Actions, 8: $113-118.1978$

15 GABELLA. G. - Structure of the antonomic nervous system. London, Chapman and Hall, 1976. 
TOPPA, N. H : LEITE. V. H. R.: BARBOSA, A. J. A.: CHIARI. E. GONZAGA, H. M. S.: FREIRE MAIA, L. \& CUNHA MELO. J. K. ... Effect of scorpion toxin on the enterochronaffin like ceils in rormal and Trypanosoma cruzi-infected rats: a morphological study. Rev. Inst Med. trop. São Paulo, 31 (1): 7.13, 1989.

16. GONZAGA. H. M. S.: ALZAMORA. F. CUNHA MELO, J. R. \& FREIRE-MAIA, L - Gastric secretion induced by seorpion toxin. Toxicon, 17: $316 \cdot 318.1979$

17. GONZAGA, H. M. S. - Açào da tityustoxina sobie a se. creçäo gástrica "in vitro" e "in vivo". Belo Horizonte. 1980. Dissertaça de mestrado - Instituto de Cienctas Biológicas da Universidade Federal de Mirias Gerais

18. HAKANSON, R. \& OWMAN, Ch - Concomitant histo chemical demonstration of histamine and catecholamine in enterochromaffin like cells of gastric mucosa Life Sci. 6: $759 \cdot 766,1967$

19. HAKANSON, R. OWMAN CH \& SOOEERG. N O Celiular store of gastrie histanine in the developing rat Life Sci., 6: 2535 2543, 1967.

20. HAKANSON, $R$ \& LIEDBERG. G -.. The role of Edoge nous gastrin in the activation of gasiric nistidine decarboxylase in the rat. Effect of antrectoiny alsd vagal denervation. Europ. J. Pharmacol. 12: 94-103 is70.

21. HAKANSON, R OWMAN Ch SFORROHG \& \&UND LER, F. -- Electron microscopic identification of histami ne-storing argyrophil (enterochromaffin like) cells in the rat stomach. Z. Zellforsch., 122: 460466,1971

22. HAKANSON. R.: LARSSON. L. I \& SUNDLER, F. . En docrine like cells in rat stomach: effects of 6 hydroxydopa on amine acid decarboxylase activities. A chemical. fluo rescence histochemical and electron microscopic study J.Pharmacol. exp. Ther., 191: 92-101.1974

23. HAKANSON, R.: LARSSON L. I: LIEDBERG G.: OS CARSON I.; SUNDLER, F. \& VANG. $J$-- Effects of an trectomy and portal shunting on the histamine storing endocrine-like cells in oxyntic mucosa of rat stomach $A$ fluorescence, histochemical. electron mieroscopic and chemical study. J. Physiol., 259: 785-800. 1976

24. KUBOTA, H ; TAGUCHI, Y.: TOHYAMA, M.: MATSU RA, N.: SHIOSAKA, S.; ISHIHARA, T.: WATANABE $T$. SHIOTANI, Y \& WADA, H. -- Electron microscopic identification of histidine decarboxylase containing endo crine cells of the rat gastric mueosa. An immunohisto chemical analysis. Gastroenterology, 87: 4965021984

25. LUNDELL, L - The role of cholinergic excitation in the formation of histamine within the rat gastric mucosa. Acta physiol seand., 97: 145 149、1976

26. MACHADO. A. B. M.: MACHADO C. R. S. \& GOMES. C. B. - Depletion of heart norepinephrine in experimental acute myocarditis caused by Trypanosama cruzi Experientia, 31: 1202-1205. 1975

27. MACHADO, C. F. S.: MACHADO, A. B. M \& CHIARI, C. A. - Recovery from heart norepinephrine depletion in experimental Chagas disease. Amer. J. trop. Med. Hyg., 27: $20-24,1978$

28. MACHADO, A. B. M.: MACHADO. C. R. S \& GOMEZ M. V. - Trypanosoma cruzi acetyicholine content and chulinergli innervation of the heart in rats. Exp. Parasit., 47. 1007.1151979 .

29. PEARSE, A. G. E \& TAKER, T. T. -- Neuroendocrine embrology and the APUD concept. Clin. Endocr. 5 (suppl): $229-280,1976$

30. RUBIN. W \& SCHWARTZ, B. - An electron microscopic radiodu tographic identification of the "enterochromaffin like" APUD cells in murine oxintic glands. Demonstration of a metabolic difference between rat and mouse gastric A like cells. Gastroenterology, 76:437 449, 1979a

si RUBIN W \&CHWARTZ B -- Electron nicroscopic radioalitograpnic identification of the ECL cells as the histamine-synthetizing endocme cell in rat stomach. Gastruenterology $77: 456-467 \quad 1979 \mathrm{~b}$

32. RUBIN, W. SCHWARTZ B -- Ideatification of the seru tonin.syintietuzing endocrine cells in the rat stomach by electron microscopic radioautographic and amine fluores cence Gastroenterology, 84, 34-50,1983

33. SANO M: HOLAN, O.: BOMBECK T: NYHUS, L $M$ \& DAS GUPTA T K - Effect of acetylcholine and cate cholamines on the enterochromaffin like cells of the sto mach Sury. Gynec. Obstet. $153: 337.340 .1981$.

34. SOLCIA E CAPELLA C : VASSALLO, $G$ \& BUFFA R. -.. Endocrine cells of the gastric mucosa. Int. Rev. Cytol., 42:223-286, 1975

35. SOLL, A. H.; LEWIN, K. J. \& BEAVEN, M. A. -.. Isolation of histamine containing cells from rat gastric mucosa bio chemical and morphological differences from mast cells. Gastroenterology, 80: 717-727, 1981

36. TAFURI. W.L. - Pathogenesis of lesions of the autonomic nervous system of the mouse in experimental acute Cha gas disease: light and electron microscope studies Amer. J. trop. Med. Hyg., 19: 405417,1970

37. TAFURI. W. L. .-. Light and electron microscope studies of the autonomic nervous system in experimental and hu man american trypanosomyasis Virchows Arch. Abi. A path. Anat., 376: $353 \cdot 360,1971$

38 TAFURI, W. L. - Alteracoes ultra-estruturais dos compo nentes muscular. intersticial e nervoso do coraçào. esofa go e intestino na Doença de Chagas experimental e humaná. Belo Horizonte. 1974. (T'ese de Professor-Titular - Fa cuidade de Medicina da Universidade Federal de Minas Gerais)

39 THUNBERG, $\mathrm{R},-$ Localization of ceils containing and forming histamine in the gastric mucosa of the rat Exp. Cell. Res., 47: 108-115, 1967

40 VASSALLO G: SOLCIA, E \& CAPELLA C - Light and electron microscopic identification of several types of endocrine cells in the gastrointestinal mucosa of the cat. Z. Zellforsch, 98: 333.356, 1969

Recebido para publicaça em 22/04:1988. 